\title{
Thematic set of papers on the Silurian System
}

\author{
Editorial preface by David K. Loydell
}

Siluria revisited was held in July 2011 as a field and indoor meeting of the International Subcommission on the Silurian System. A field guide (Ray 2011, available also from the IGCP 591 website: http://igcp591.org/downloads/siluria_revisited_excursion_2011.pdf) was published to accompany the pre- and post-conference field trips. Those attending the meeting were invited to submit papers on any aspect of the Silurian System and this issue of the Bulletin of Geosciences is the result. Topics covered range from conodont and graptolite biostratigraphy (Corradini \& Corriga 2012, Loydell 2012 , Legrand 2012) through carbon isotope stratigraphy (Marshall et al. 2012) and excursions integrated into automated stratigraphic correlations (Sadler 2012), correlations based upon metabentonites (Kiipli et al. 2012) and digital integrated stratigraphy (Munnecke et al. 2012), to systematic study on scolecodonts (Tonarová et al. 2012). The conference papers are supplemented by four other papers devoted to various aspects of the Silurian System and its biota (Brett et al. 2012, Storch \& Schönlaub 2012, Turek \& Manda 2012, Slavík \& Carls 2012). I hope that you enjoy reading the papers presented here and find them useful for your research.

I thank: Jiří Frýda and Štěpán Manda, editors of the Bulletin of Geosciences, for providing the opportunity to publish this thematic set of papers; all of the referees for their constructive criticisms of the original submissions; and, finally, Šárka Doležalová for her hard work in seeing this thematic set through from submission to final publication.

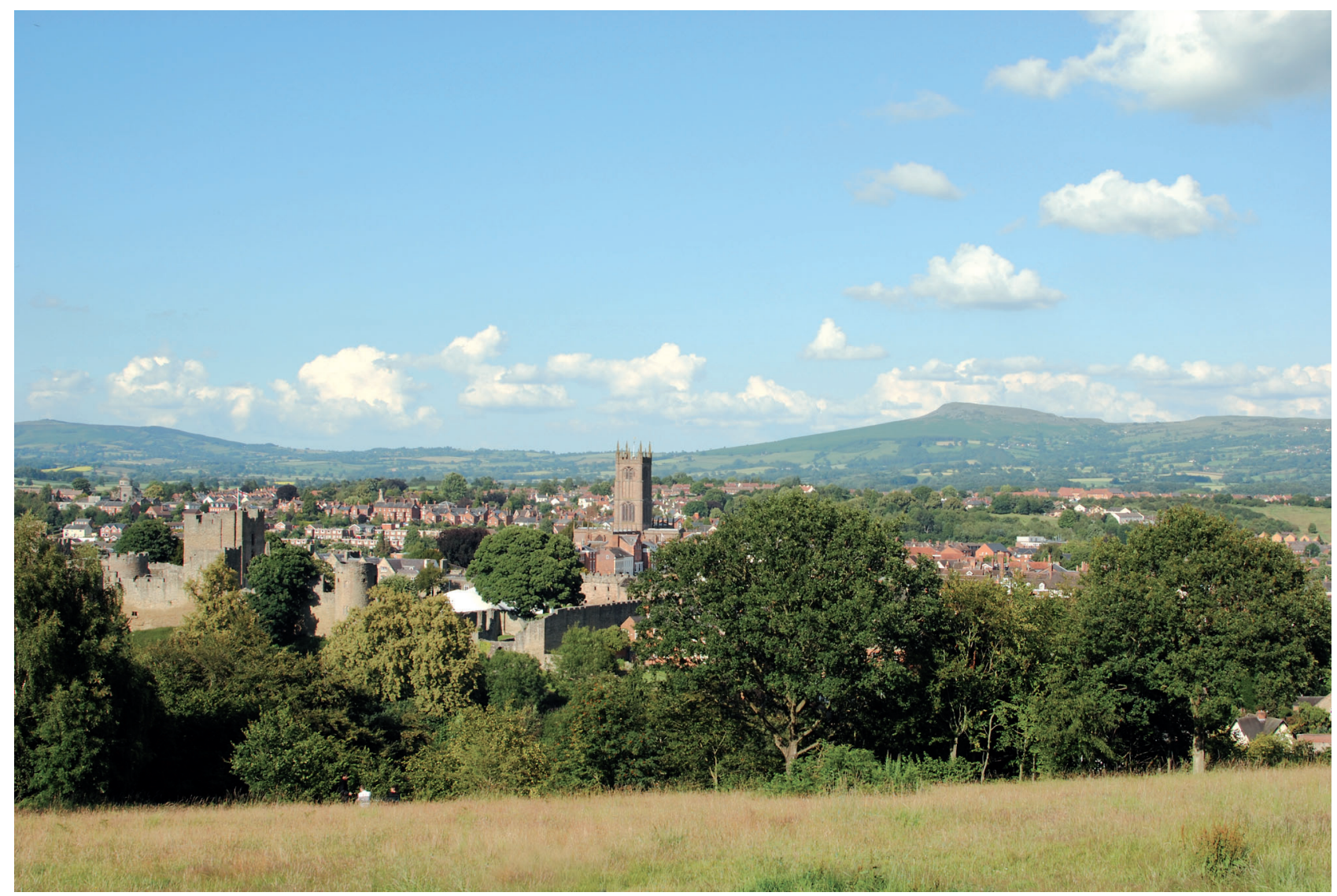

Ludlow Castle and Ludlow town which hosted biannual meeting of the ISSS in July 2012; view from Whitcliffe ridge (photo by Anthony Butcher). 


\section{References}

Brett, C.E., Cramer, B.D., McLaughlin, P.I., KlefFner, M.A., Showers, W.J. \& ThomкA, J.R. 2012. Revised TelychianSheinwoodian (Silurian) stratigraphy of the Laurentian midcontinent: building uniform nomenclature along the Cincinnati Arch. Bulletin of Geosciences 87(4), 733-753. DOI 10.3140/bull.geosci.1310

Corradini, C. \& Corriga, M.G. 2012. A Přídolí-Lochkovian conodont zonation in Sardinia and the Carnic Alps: implications for a global zonation scheme. Bulletin of Geosciences 87(4), 635-650. DOI 10.3140/bull.geosci.1304

KiIpli, T., Radzievičius, S., Kallaste, T., KiIpli, E., Sirr, S., Soesoo, A. \& Voolma, M. 2012. The Geniai Tuff in the southern East Baltic area - a new correlation tool near the Aeronian/Telychian stage boundary, Llandovery, Silurian. Bulletin of Geosciences 87(4), 695-704. DOI 10.3140/bull.geosci.1313

LEgRAnd, P. 2012. The upper Silurian of Touat (Algerian Sahara) and its fauna. Bulletin of Geosciences 87(4), 661-668. DOI 10.3140/bull.geosci.1305

LOYDELL, D.K. 2012. Graptolite biostratigraphy of the E1-NC174 core, Rhuddanian (lower Llandovery, Silurian), Murzuq Basin (Libya). Bulletin of Geosciences 87(4), 651-660.

DOI 10.3140/bull.geosci.1311

Marshall, C., Thomas, A.T., Boomer, I. \& Ray, D.C. 2012. High resolution $\delta^{13} \mathrm{C}$ stratigraphy of the Homerian (Wenlock) of the English Midlands and Wenlock Edge. Bulletin of Geosciences 87(4), 669-679. DOI 10.3140/bull.geosci.1306

Munnecke, A., Cramer, B.D., Boon, D.P., Kharwat, R., Aiken, C.L. \& Schofield, D.I. 2012. The Digital Integrated Stratigraphy Project (DISP). Bulletin of Geosciences 87(4), 705-712. DOI 10.3140/bull.geosci.1318

RAY, D.C. (ed.) 2011. Siluria revisited: a field guide. International Subcommission on Silurian Stratigraphy, Field Meeting 2011. 170 pp. MPG Books, Bodmin.

SADLER, P.M. 2012. Integrating carbon isotope excursions into automated stratigraphic correlation: an example from the Silurian of Baltica. Bulletin of Geosciences 87(4), 681-694. DOI 10.3140/bull.geosci.1307

SlavíK, L. \& CARLS, P. 2012. Post-Lau Event (late Ludfordian, Silurian) recovery of conodont faunas of Bohemia. Bulletin of Geosciences 87(4), 815-832. DOI 10.3140/bull.geosci.1368

ŠToRCh, P. \& SchÖNlaub, H.-P. 2012. Ordovician-Silurian boundary graptolites of the Southern Alps, Austria. Bulletin of Geosciences 87(4), 755-766. DOI 10.3140/bull.geosci.1350

Tonarová, P., Eriksson, M.E. \& Hints, O. 2012. A jawed polychaete fauna from the late Ludlow Kozlowskii event interval in the Prague Basin (Czech Republic). Bulletin of Geosciences 87(4), 713-732. DOI 10.3140/bull.geosci.1317

TureK, V. \& MANDA, Š. 2012. "An endocochleate experiment" in the Silurian straight-shelled cephalopod Sphooceras. Bulletin of Geosciences 87(4), 767-813.

DOI 10.3140/bull.geosci.1335 